\title{
FARMERS' DECISIONS AND DETERMINANTS OF CROP ROTATIONS WITH LUPIN: THE CASE OF WEST AMHARA REGION, ETHIOPIA
}

\author{
Beneberu TEFERRA *l, Likawent YEHEYIS ${ }^{2}$, Matthew NELSON ${ }^{3}$, Jemma TAYLOR ${ }^{3}$, \\ David MCNAUGHTON ${ }^{4}$, Andrew SERGEANT ${ }^{5}$, Heather SANDERS ${ }^{6}$
}

\author{
Address: \\ ${ }^{1}$ Debre Birhan Agricultural Research Center, P.O.Box, 112, Debre Birhan, Ethiopia \\ ${ }^{2}$ Amhara Agricultural Research Institute, P.O.Box, 527,Bahir Dar, Ethiopia \\ ${ }^{3}$ The Royal Botanic Gardens, Kew, Richmond, Surrey TW9 3AB,UK \\ ${ }^{4}$ Soya UK Ltd, Longways house, Burnetts Lane, Southampton, SO30 2HH, UK \\ ${ }^{5}$ Farleigh Cottage, Claverton, Bath, BA2 7BG, UK \\ ${ }^{6}$ Secure Harvests Ltd, 17 Winsley Road, Bradford on Avon, BA15 1QS, UK \\ *Corresponding author: beneberu2001@yahoo.com
}

\begin{abstract}
Using lupin as a break crop and for soil fertility improvement is one of the practices to enhance productivity and improve soil fertility in Ethiopian conditions. However, the use of this practice by smallholder farmers is limited. Therefore, the major objective of this study was to empirically examine factors influencing farmers' decision to allocate land for lupin crop production as a break crop in North Western Amhara Region of Ethiopia. In this study, stratified sampling procedure was used to select 253 sample households from four Districts (137 household who use lupin in their crop rotations and 116 that do not). The required data were collected using interviews with a structured questionnaire. Logistic regression analysis was used to identify factors influencing farmers' decision to allocate land for lupin production as a break crop. The results of the logit regression analysis indicate that family size, total farmland holdings and contacts with extension workers were the most important factors influencing the decision of the farmer to practice crop rotation with lupin. Hence, emphasis should be given to improve the human capital through training and providing extension service to bring farmers' awareness to practice improved technologies and best indigenous knowledge.
\end{abstract}

Keywords: Lupin; Crop rotation; Determinants; Logit; Ethiopia

JEL: C13, C25, D13

\section{INTRODUCTION}

Ethiopia's socio-economic feature is predominantly rural and agriculture is a key driver of the country's long-term growth and food security. About $85 \%$ of the population is in rural parts of the country and agriculture directly supports 83 percent of the population, constitutes 41 percent of Gross Domestic Product (GDP), and 90 percent of export value (EEA, 2012). However, complex and widespread poverty, food insecurity, low productivity, famine and degradation of natural resources are among the challenges facing the country (David et al., 2011).

Traditional mixed crop livestock production system is practiced by subsistence farmers, focusing on household food security. Ethiopia is rich in its livestock resources with 59.5 million cattle, 30.70 million sheep, 30.20 million goats, 2.16 million horses, 8.44 million donkeys, 0.41 million mules, and about 1.21 million camels in the sedentary areas of the country (CSA, 2017). However, the productivity and reproductive efficiency is very low. On the other hand, the demand for livestock products is increasing due to population growth, urbanization and relative improvement of the economy.

According to the Ethiopian livestock master plan (LMP, 2014), if no investment is made in raising livestock productivity, in the year 2028 there will be a deficit of $42 \%$ and $23 \%$ in meat and milk (respectively) in the country due to exploding demand. In the mixed crop livestock production system, the most limiting nutrient in livestock feed is protein. Moreover, concentrated feed supplements are either inaccessible or too expensive for most Ethiopian smallholder farmers. Hence homegrown protein supplements like lupin are very important options to solve the burden of livestock feed supplement in the country beside its importance for market and soil fertility improvement being as a precursor crop for major crops like teff, wheat, maize and others.

According to IFPRI (2010), Ethiopia also faces a wide set of soil fertility issues that require approaches that go beyond the application of chemical fertilizers, the only practice applied at scale to date. Moreover, acidity of the soil (covering over 40 percent of the country), significantly depleted organic matter due to widespread use of biomass as fuel, exhausted macro and micronutrients, and reduction of soil physical properties are among the core constraints to agricultural productivity and sustainability in Ethiopia. The problem is particularly serious in the western part of the Amhara region. The population growth rate $(2.6 \%)$ in the country appears to be greater than the agricultural production rate $(2.3 \%)$ 
contributing to the food insecurity and environmental degradation (Bachewe, et al, 2015; Getachew and Ranjan, 2012).

One way to tackle this problem is to adopt scientific, cost effective and environmentally friendly production methods such as crop rotation. Crop rotation can be defined as growing crops in a planned sequence on the same field. The principle is to grow annual crops on a different piece of land each year, ensuring that they do not return to the same spot for at least 2 years. Crop rotation has many agronomic, economics and environmental benefits. It improves soil structure with higher levels of organic matter and better water provision resulting in higher yields in the long-term (EU DGE, 2012). It creates a more balanced nutrient cycle at the field level and helps farmers to use fewer inputs to maintain nutrient availability that results in lowering costs and increasing profit margins. Lupin species are particular effective in raising soil fertility through symbiotic nitrogen fixation and mobilization of soil phosphorus (Peoples, et al, 2009a; Lambers et al, 2013). Rotation also provides an important break in the disease cycle of crops (Kirkegaard et al., 2008). Break crop benefits provided by narrowleafed lupin were detectable up to the third cereal crop after lupin (Seymour et al., 2012).

Despite these clear benefits, most of farmers in the study districts do not utilize this practice effectively. Considering this fact, this study tried to look factors that affect farmers' decision to adopt crop rotation practice with lupin in the study areas. Knowledge of the extent and causes of such factors will guide policy makers to help increase of agricultural production by designing more effective and efficient institutional support service.

\section{DATA AND METHODS}

\section{The Study Area}

Four districts namely, Machakel, Sekela (in East Gojam), South Achefer (in West Gojam) and Dera (in South Gondar) were selected because these districts have potential for lupin production as they have acidic and brown clay soil and farmers have experience in using lupin as a break crop for rotation (Figure 1).

\section{Method of Sampling}

A multistage sampling procedure was used to select farmers for the survey. The survey was focused on four districts and ten kebeles (Kebeles represent the lowest administrative unit in the Ethiopia). A total of 253 households were randomly selected and identified as adopters (those farmers practicing crop rotation with lupin) or non-adopters of lupin in their crop rotations. Farmers differed in their experience of crop rotation with lupin. Hence, in this study, those farmers typically having more than one field that practiced crop rotation with lupin for two and more consecutive years were considered as adopters and otherwise considered as non-adopters. The sample size for the study was determined based on Kothari (2004) (Eq. 1).
$n=\frac{Z^{2} p q N}{e^{2}(N-1)+Z^{2} p q}$

Where: $n$ is the desired sample size, $Z$ is the inverse of the standard cumulative distribution that corresponds to the level of confidence with the value of 1.96. $\mathrm{p}$ is the estimated proportion of an attribute present in the population and $q=1-p . \mathrm{N}$ is the size of the total population from which the sample is drawn. Assuming large population but the variability is not known in the proportion about the inputs use, $p=0.5$ is considered as suggested by Israel (1992) to get the desired minimum sample size at $95 \%$ confidence level and $\pm 8 \%$ precision (e).

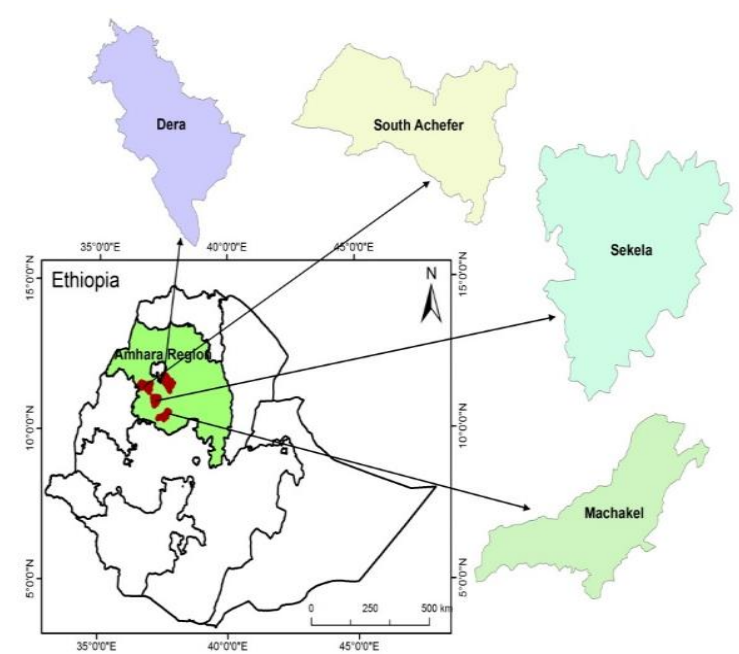

Figure 1. Map of the study areas in the Amhara Region of Ethiopia.

Accordingly, data were collected from both groups using interview schedule at the same time. To give equal chance in selection of the study units from each of the group, probability proportional to size was applied. Consequently, 137 household adopters and 116 nonadopters of crop rotation with lupin were selected.

The survey was conducted in January 2018. Enumerators with local knowledge were recruited and trained in the class as well as in the field. The questionnaire was pre-tested. The pre-test for the survey was conducted in-class training and field practice days. Some of the trainees had some experience with household surveys. Following field practice, a debriefing session was held with the enumerators and modifications to the questionnaires were made based on lessons drawn from the exercise.

\section{Method of Data Analysis}

Various qualitative econometric models, such as Linear Probability Model (LPM), Logit, Probit and Tobit Models can be used to establish the relationship between household characteristics and a dichotomous dependent variable. The Logit and Probit models are usually the most commonly used ones. Gujarati (1995) states that one can easily use the cumulative distribution function to model regression where the response variable is dichotomous. 
Table 1. Distribution of sample farm household heads by district and kebeles

\begin{tabular}{|c|c|c|c|c|c|c|c|c|c|c|c|}
\hline \multirow[t]{2}{*}{ Districts } & \multirow[t]{2}{*}{$\begin{array}{l}\text { Total } \\
\text { Househol } \\
\text { d Heads } \\
\text { No. }\end{array}$} & \multicolumn{2}{|c|}{$\begin{array}{l}\text { Adopters } \\
\text { sample } \\
\text { households } \\
(\mathrm{N}=137)\end{array}$} & \multicolumn{2}{|c|}{$\begin{array}{l}\text { Non- } \\
\text { Adopters } \\
\text { Sample } \\
\text { households } \\
(\mathrm{N}=116)\end{array}$} & \multirow[t]{2}{*}{ Kebeles } & $\begin{array}{l}\text { Total } \\
\text { Househol } \\
\text { d Heads }\end{array}$ & \multicolumn{2}{|c|}{$\begin{array}{l}\text { Adopters } \\
\text { sample } \\
\text { households( } \\
\mathrm{N}=137)\end{array}$} & \multicolumn{2}{|c|}{$\begin{array}{l}\text { Non- } \\
\text { Adopters } \\
\text { Sample } \\
\text { households } \\
(\mathrm{N}=116)\end{array}$} \\
\hline & & No. & $\%$ & No. & $\%$ & & No. & No. & $\%$ & No. & $\%$ \\
\hline \multirow[t]{3}{*}{ Machakel } & 23732 & 46 & 33.6 & 31 & 26.7 & Debrekelemu & 840 & 32 & 27.6 & 1 & 0.9 \\
\hline & & & & & & Amareyew ubish & 687 & 0 & 0 & 30 & 25.9 \\
\hline & & & & & & Amanuel Zuria & 864 & 14 & 12.1 & 0 & 0 \\
\hline \multirow[t]{2}{*}{ Sekela } & 23914 & 27 & 19.7 & 25 & 21.6 & Abaysengif & 969 & 27 & 23.3 & 21 & 18.1 \\
\hline & & & & & & Zegezatengeta & 595 & 0 & 0 & 4 & 3.4 \\
\hline South & 26400 & 23 & 16.8 & 17 & 14.7 & Abchekli Zuria & 1836 & 23 & 19.8 & 17 & 14.7 \\
\hline \multicolumn{12}{|l|}{ Achefer } \\
\hline \multirow[t]{4}{*}{ Dera } & 51998 & 41 & 29.9 & 43 & 37.1 & Huletwegedame & 1565 & 23 & 19.8 & 9 & 7.8 \\
\hline & & & & & & Tebabari & 1416 & 11 & 9.5 & 18 & 15.5 \\
\hline & & & & & & Emashenkore & 1471 & 5 & 4.3 & 16 & 13.8 \\
\hline & & & & & & Gedamgeregera & 2996 & 2 & 1.7 & 0 & 0 \\
\hline Total & & 137 & 100 & 116 & 100 & & & 137 & 100 & 116 & 100 \\
\hline
\end{tabular}

Source: DADO, 2017, respective kebeles' records and survey results.

The advantages of these models over the Linear Probability model are that the probabilities are bound between 0 and 1 . Moreover, they best fit to the nonlinear relationships between the response and the explanatory variables.

The dependent variable in this case is dichotomous in nature and takes value of zero or one; where zero represents non-adopters crop rotation with lupin and one represents adopters. Crop rotation with lupin is, therefore, a non-continuous dependent variable, which does not satisfy the key assumption in linear regression analysis; that is, a continuous value for dependent variable. Therefore, the study used logistic probability unit (logit) to examine the kind of relationship that exists between adoption decision and the various socio- economic and demographic factors. Hosmer and Lemeshow (1989) stated that the logistic distribution has advantage over the others, in the analysis of dichotomous outcome variables, because it is extremely flexible and easily used model from mathematical point of view and results in meaningful interpretations. Following the explanation of Gujarati (1995), the Logit model is specified as in Eq. 2.

$P_{i}=E\left(Y=1 \mid x_{i}\right)=\frac{1}{1+e^{-\left(\beta_{0}+\beta_{1} x_{i}\right)}}$

Where:

$P_{i}$ is the probability of being adopter ranging from 0 to 1 $Y$ is the probability of an event to occur or not.

$X_{i}$ is a vector of relevant household characteristics

For ease of explanation, equation (2) can be expressed as in Eq. 3:

$P_{i}=\frac{1}{1+e^{-z} i}=\frac{e^{z}}{1+e^{z}}$

Where:

$z_{i}=\beta_{0}+\beta_{1} x_{i}$

$Z i$ is a function of $n$-explanatory variables $\left(x_{i}\right)$ and $z_{i}$ ranges from $-\infty$ to $+\infty$; $x_{i}$ is a vector of relevant household characteristics.

If $P_{i}$ is the probability of being adopter then the probability of non-adopter is given by $1-P_{i}$, which is expressed as in Eq. 4.

$1-P_{i}=\frac{1}{1+e^{z_{i}}}$

Therefore, Eq. 4 can be written as Eq. 5:

$\frac{P_{i}}{1-P_{i}}=\frac{1+e^{z_{i}}}{1+e^{-z_{i}}}=e^{z_{i}}$

Where $P_{i} /\left(1-P_{i}\right)$ is the odds ratio in favour of adopter; the ratio of the probability that the household will be adopter to the probability that it will be non-adopter. Now if one takes the natural $\log$ of Eq. 5 it is possible to arrive at a log of odds ratio, which is linear not only in x's but also in the parameters (Eq. 6).

$L_{i}=\ln \left(\frac{P_{i}}{1-P_{i}}\right)=z_{i}=\beta_{0}+\beta_{i} L x_{i}$

Where:

$L_{i}$ is $\log$ of odds ratio

If the disturbance term $\left(U_{i}\right)$ is introduced, the logit model becomes as in Eq. 7.

$z_{i}=\beta_{0}+\beta_{i} x_{i}+U_{i}$

\section{RESULTS AND DISCUSSION}

\section{Descriptive statistics}

\section{Households Characteristics}

The average age of sample household heads was found to be 46.1 years with standard deviation of 13.15 . From the total sample households, about $15.4 \%$ were younger or equal to 30 years. The majority of the household heads (73.9\%) were found in the age ranges of 31 and 64 years whereas; about $10.7 \%$ were older than 64 years. The average family size of the sample households was 5.64 
persons, which is larger than the rural national (4.90) and the regional (4.50) averages, respectively (EDHS, 2016).

Farmers in the sample households attend on average 5.7 ( \pm 2.66$)$ formal schooling years and about $67 \%$ of the sample households' heads were able to read and write even though they did not attain formal schooling. Except family size for adoption status, all variables do not have significant difference $(\mathrm{p}>0.05)$ between practicing status and across districts (Table 2).

\section{Socio-economic characteristics}

The main resource needed by farmers to earn their livelihoods is land. It is the primary and dependable means of living for the rural people of the country as a whole. The average land owned by the farmers in the study area is 1.22 ha with the minimum and maximum value of 0.0 and 4 ha respectively. The average landholding size is higher as compare to the national average (1.14 ha) and comparable to the regional average (1.21ha) per household (CSA, 2014). It also showed in the study that about $8.3 \%$ of sample farmers were landless and about $50.2 \%$ of the farmers owned land less than 1.00 ha. Moreover, about $35.2 \%$ of households owned land between $1.00-2.00$ hectares followed by $12.3 \%$ of households holding land size between 2.01 to 3.00 hectares and only about $2.4 \%$ of households having land size between 3.01 to 4.00 hectares. In the survey it is shown that farmers allocated their land for lupin is not more than $5 \%$ of the total land cultivated (Table 3 ).

Table 2. Descriptive statistics of household characteristics between districts, $(\mathrm{N}=253)$

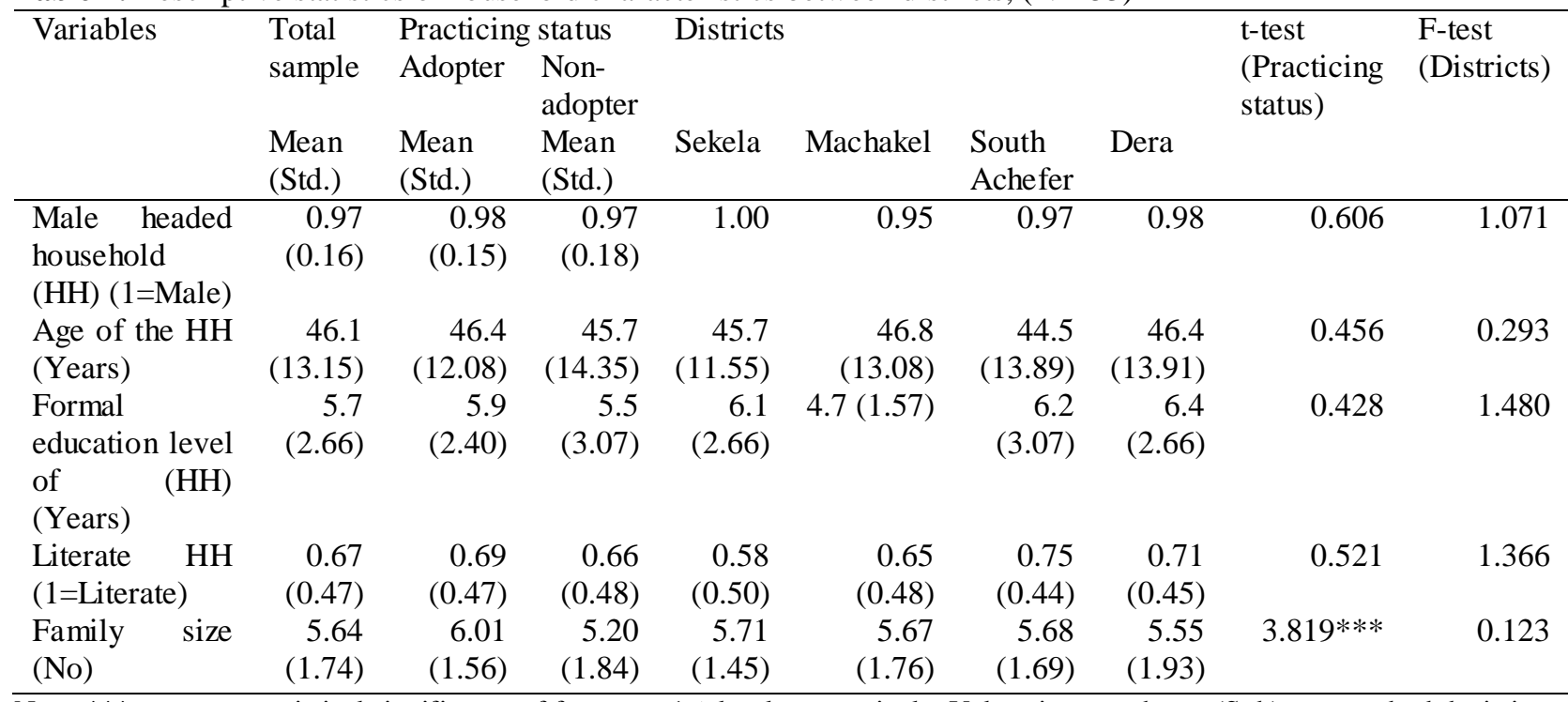

Note: *** represent statistical significance of factors at $1 \%$ levels respectively. Values in parentheses (Std.) are standard deviations. $\mathrm{HH}=$ Headed Household

Source: Computed from survey data (2018)

Table 3. Proportion of Lupin land to all land cover of sample households across district, 2016/17.

\begin{tabular}{|c|c|c|c|c|c|c|c|c|}
\hline \multirow{3}{*}{$\begin{array}{l}\text { Major } \\
\text { crops }\end{array}$} & \multicolumn{8}{|c|}{ Districts name } \\
\hline & Sekela & & Machakel & & South Achefer & & Dera & \\
\hline & land cover (ha) & $\%$ & land cover (ha) & $\%$ & land cover (ha) & $\%$ & land cover (ha) & $\%$ \\
\hline Teff & 2389 & 10.99 & 6365 & 15.32 & 5808 & 14.85 & 1410 & 2.23 \\
\hline Wheat & 2524 & 11.61 & 9727 & 23.41 & 1633 & 4.17 & 5846 & 9.23 \\
\hline Barley & 4163 & 19.16 & 2865 & 6.89 & 4512 & 11.53 & 3547 & 5.60 \\
\hline $\begin{array}{l}\text { Finger } \\
\text { millet }\end{array}$ & 1315 & 6.05 & 473 & 1.14 & 6377 & 16.30 & 12157 & 19.20 \\
\hline Maize & 3684 & 16.95 & 7885 & 18.97 & 14843 & 37.94 & 13880 & 21.92 \\
\hline Potato & 4733 & 21.78 & 3269 & 7.87 & 737 & 1.88 & 5760 & 9.10 \\
\hline Lupin & 544 & 2.50 & 427 & 1.03 & 2061 & 5.27 & 2822 & 4.46 \\
\hline Other & 2380 & 10.95 & 10547 & 25.38 & 3151 & 8.05 & 17886 & 28.25 \\
\hline crops & & & & & & & & \\
\hline All crops & 21732 & 100. & 41558 & 100. & 39122 & 100. & 63308 & 100. \\
\hline
\end{tabular}

Source: Respective districts records (2018) 
Table 4. Livestock holding in Total Livestock Unit (TLU) by the sample households across district, 2018.

\begin{tabular}{lccl}
\hline District name & Sample households No & Mean in TLU & Std. Deviation \\
\hline Machakel & 77 & 6.71 & 2.593 \\
Sekela & 52 & 4.37 & 1.585 \\
South Achefer & 40 & 7.36 & 3.129 \\
Dera & 84 & 4.60 & 2.069 \\
Total & 253 & 5.63 & 2.640 \\
\hline
\end{tabular}

Source: Computed from survey data (2018)

Table 5. Trend of land holding, allocation of land to lupin and yield per household, 2015 - 2018.

\begin{tabular}{|c|c|c|c|c|c|c|c|c|c|c|c|c|}
\hline & \multicolumn{4}{|c|}{ Total land cultivated (ha) } & \multicolumn{4}{|c|}{ Total land under lupin (ha) } & \multicolumn{4}{|c|}{ Average lupin yield $\left(\mathrm{t} \mathrm{ha}^{-1}\right)$} \\
\hline Year & $2014 / 15$ & $2015 / 16$ & $2016 / 17$ & $2017 / 18$ & $2014 / 15$ & $2015 / 16$ & $2016 / 17$ & $2017 / 18$ & $2014 / 15$ & $2015 / 16$ & $2016 / 17$ & $2017 / 18$ \\
\hline $\mathrm{N}$ & 73 & 137 & 137 & 137 & 57 & 137 & 137 & 137 & 24 & 125 & 132 & 127 \\
\hline Min & 0 & 0.5 & 0.5 & 0 & 0 & 0 & 0 & 0 & 0.4 & 0 & 0.12 & 0.2 \\
\hline $\operatorname{Max}$ & 3 & 3.75 & 3.75 & 3.75 & 0.5 & 1.25 & 1 & 1 & 1.6 & 2.8 & 3.2 & 3.2 \\
\hline Mean & 1.24 & 1.59 & 1.62 & 1.62 & 0.09 & 0.25 & 0.29 & 0.28 & 0.95 & 1.03 & 1.1 & 1.11 \\
\hline $\begin{array}{l}\text { Std. } \\
\text { Dev. }\end{array}$ & 0.939 & 0.697 & 0.705 & 0.738 & 0.128 & 0.166 & 0.161 & 0.183 & 0.352 & 0.558 & 0.606 & 0.547 \\
\hline
\end{tabular}

Source: Computed from survey data (2018)

Respondent farmers on average own $5.63( \pm 2.64)$ total livestock units (TLU) ranging from 0.0 to 18.25 values and nearly $58 \%$ of the respondents have more than 5 TLU whereas, $8 \%$ of the respondents possess more than 10 TLU (FAO, 2004). Table 4 depicts livestock distribution among the study districts.

\section{Lupin Production}

For those farmers who practiced crop rotation with lupin, in all the study areas, about $83.2 \%$ produced only the bitter lupin types, the rest farmers $(16.8 \%)$ in district of South Achefer produced both bitter and sweet lupin. In this district, there are some research interventions on sweet lupin on feeding trials by the Andassa Agricultural Research Center. Yield of lupin was computed based on total grain output per unit of land for those who produce the crop and expressed as tonnes per hectare of land ( $\mathrm{t} / \mathrm{ha})$. Hence, taking 2017/18 production year, the average yields were $1.11 \mathrm{t} \mathrm{ha}^{-1}$ with minimum and maximum value of 0.2 and $3.2 \mathrm{t} \mathrm{ha}^{-1}$ respectively (Table 5). There is an upward trend both in yield and land allocation for lupin in the study areas.

Table 6. Reasons for lupin production in the study areas, measured in percentage, $\mathrm{N}=137$.

\begin{tabular}{lrr}
\hline Reasons for lupin production & Yes & No \\
\hline Crop rotation to increase soil fertility & 92.7 & 7.3 \\
Favorable land and climatic condition & 12.4 & 87.6 \\
Current market demand for lupin & 62.0 & 38.0 \\
Household consumption & 35.0 & 65.0 \\
Crop diversification & 4.4 & 95.6 \\
Livestock feed & 2.2 & 97.8 \\
High productivity of the crop & 6.6 & 93.4 \\
For fattening of sheep and goats & 5.1 & 94.9 \\
\hline
\end{tabular}

Source: Computed from survey data (2018)

Most farmers (74\%) plant lupin after a single plough whereas, the rest plant lupin without ploughing at the onset of the rainy season. Sampled farmers used only improved sweet lupin seed (12.4\%) only at South Achefer district. Other district did not use any improved inputs as they thought no need of inputs $(44.5 \%)$ for lupin production and some also said because of lack of awareness (30\%). There is no effective training particularly in lupin production. This could be confirmed from survey result that about $78 \%$ of the sample farmers who grow lupin did not get training on lupin production practices. However, Andassa Agricultural Research Center trained farmers in livestock feeding and their extension agents trained farmers how to make green manure using lupin plants in 2017.

Shortage of feed in terms of quality and quantity is one of the leading problem especially during the long dry season because the main feed source is pasture and the farmers lack in experience of feed conservation (Zewdie, 2015). To alleviate this problem different options should be considered. For instance, local bitter white lupin is a very important traditional multipurpose crop and it is grown in mixed crop livestock farming systems of the area (Yeheyis et al., 2010). Therefore, sweet lupin can be used as an alternative source of feed for mid and high-altitude areas of Ethiopia. According to Yeheyis et al., 2011, feeding trial on Washera sheep (on station) supplementing with $290 \mathrm{~g} / \mathrm{head} /$ day sweet lupin grain have average daily body weight gain of $74 \mathrm{~g} /$ day and final body weight of $26.1 \mathrm{~kg}$. In the demonstration made by Molla, et al., 2017 at the Debre Mewi watershed in western Amhara Region, it was found that a $290 \mathrm{~g} / \mathrm{head} /$ day sweet lupin grain supplementation increases the live weight of experimental animals on average from $21.9 \mathrm{~kg}$ to $29.4 \mathrm{~kg}$.

\section{Lupin marketing}

Most farmers produce lupin for market and very few for livestock fattening. Farmers sell their lupin grain for whole sellers $(54 \%)$, retailers $(24 \%)$, other farmers $(2.2 \%)$, consumers $(2.9 \%)$ and combination of all $(4.3 \%)$. The majority of farmers sell their lupin grain at local market $(54.7 \%)$ and at home as market point $(29.9 \%)$ and some in both places $(2.2 \%)$. Few farmers make lupin snacks and sold to retailers (4.4\%) and consumers (1.5\%) at local markets. Farmers are motivated to produce lupin as it improves soil fertility and requires minimum labour 
for production. Based on the observation, there is an increase in demand for lupin snack at homes, groceries and local beer sellers. This brought price increment for lupin and farmers said that they are encouraged to produce more and allocate more land with intensive practice. Farmer to farmer lupin seed exchanges (gifts, bartering) do take place, however, only limited quantities of seed are being sold directly between farmers as they save the necessary seed from previous harvest. In the absence of wellestablished value chain for seed, it is very difficult to assess the actual demand for quality seed (seed that not be wrinkled, cracked and too small). Therefore, efforts to produce quality seed would need to link producers to either institutional or private buyers.

\section{Lupin Consumption}

Based on the survey, consumption of lupin at the farm household level is limited (35\% as shown in Table 6 due to a social taboo that says, "Lupin is for the poor and it is unsuitable nutrition". Farmers consume about $13.7 \%$ of what they produced (Table 7). However, farmers also recognized that the potential health benefits of lupin, particularly positive effects on blood pressure. Similar studies showed that the consumption of foods supplemented with narrow-leaf lupin flour produced small but statistically significant decreases in blood pressure versus the control foods (Belski, et al., 2011; Lee, et al., 2009).

\section{Estimated Results}

All validation tests i.e., multicollinearity (VIF test), model specification (linktest), variable omission (ovtest) and heteroscedasticity (hettest) were made. The results confirmed no problem showed in all tests. In the estimated model the largest VIF test result was 1.53 and the mean VIF was 1.19. Moreover, the value of linktest, ovtest and hettest were hatsq $>0.05$, prob $>\mathrm{F}=0.1836$ and prob $>$ $\mathrm{chi}^{2}=0.7257$, respectively. From the econometric outputs, the following variables were statistically significant in affecting the decision of farmers to practice crop rotation with lupin.

Family size (Number of persons in the household): Though lupin production is not labour-intensive currently, as farmers do not spend much time on their lupin fields, the result showed that for a one-unit increase in family size, we expect a 0.332 increase in the log -odds of crop rotation with lupin, holding all other independent variables constant. Therefore, farmers' decision on the adoption of crop rotation with lupin dependent on the availability of labour force in the household.

Land holding Size (ha): This refers to the total farmland that a farmer owns measured in hectares. Farmers operating on a larger area of land generally allocate part of it for lupin as a break crop for the subsequent production year with major crops like teff, wheat maize or others. The result showed that for a one-unit increase in farmland holdings, it is expected to have a 0.794 increase in the log odds of crop rotation with lupin, holding all other independent variables constant. It affects farmers' decision of crop rotation with lupin positively and significantly at $1 \%$ level.

Table 7. Production, consumption and marketing per household of lupin, 2017.

\begin{tabular}{lllllr}
\hline Descriptions & $\mathrm{N}$ & Minimum & Maximum & Mean & Std. Deviation \\
\hline Total Production, kg & 130 & 0 & 1200 & 322.5 & 200.13 \\
Home consumption, kg & 129 & 0 & 400 & 44.1 & 54.14 \\
Used for seed, kg & 127 & 0 & 100 & 12.2 & 24.93 \\
Bitter lupin sold, kg & 129 & 0 & 900 & 257.2 & 182.55 \\
Sweet lupin sold, kg & 129 & 0 & 300 & 6.4 & 36.55 \\
\hline
\end{tabular}

Source: Computed from survey data (2018)

Table 8. Maximum likelihood estimates of the logit model

\begin{tabular}{lllllr}
\hline Variables & Coefficients & $\begin{array}{l}\text { Robust } \\
\text { Std. Err. }\end{array}$ & Odds Ratio & $\begin{array}{l}\text { Robust } \\
\text { Std. Err. }\end{array}$ & $\begin{array}{l}\text { Marginal } \\
\text { Effect } \\
\text { (dy/dx) }\end{array}$ \\
\hline Sex (Dummy) & & & & 0.175 \\
Age (Year) & 0.704 & 0.841 & 2.021 & 0.700 & -0.006 \\
Education (Dummy) & -0.025 & 0.015 & 0.976 & 0.015 & 0.064 \\
Family Size (Number) & 0.257 & 0.354 & 1.293 & 0.458 & 0.083 \\
Total landholding (ha) & $0.332^{* * *}$ & 0.098 & $1.394^{* * *}$ & 0.136 & 0.197 \\
Livestock holding (TLU) & $0.794^{* * *}$ & 0.259 & $2.212^{* * *}$ & 0.573 & 0.034 \\
Market Distance (km) & $0.135^{*}$ & 0.067 & $1.144^{*}$ & 0.077 & 0.001 \\
Extension contact (Dummy) & 0.004 & 0.005 & 1.004 & 0.005 & 0.112 \\
Constant & $0.451^{* * *}$ & 0.161 & $1.570^{* * *}$ & 0.253 & - \\
Log likelihood = -358.333 & $-4.124^{* * *}$ & 1.165 & $0.0162^{* * *}$ & 0.019 & \\
LR chi2(8) = 52.94 & & & & \\
Pseudo R2 = 0.187 & Prob > chi2 $=0.000$ & & & \\
\hline Source: model results & No. Observations $=253$ & & & \\
\end{tabular}


Livestock holding (TLU): The result showed that for a one-unit increase in livestock holdings, it is expected to have a 0.135 increase in the log odds of crop rotation with lupin, holding all other independent variables constant. It affects farmers' decision of crop rotation with lupin positively and significantly at $10 \%$ level.

Extension contacts (dummy): This is a dummy variable, which measures whether a farmer has contacts with extension workers or not in a year. It has positive influence on farmers' decision of crop rotation with lupin (significant at $1 \%$ level). The higher the linkage between farmers and extension workers, the more the information flows and the technological (knowledge) transfer from the latter to the former.

\section{CONCLUSIONS AND RECOMMENDATIONS}

According to the results of this study the probability of practicing crop rotation with lupin appears to be significantly and positively influenced by family size, total farmland holdings, livestock holdings and the level of contact with agricultural extension workers.

As the market price is increasing for lupin, this will made farmers encourage in producing and allocating more land with intensive practice. This intensive practice needs more labour. Therefore, this will be a good opportunity for rural labour employment. Hence, local government should design their development strategies towards improving the marketing system of lupin to benefit all actors.

Lupin production is done traditionally with low inputs. However, the current market demand for the crop might encourage farmers to produce lupin with more intensive farming approaches. This requires more land allocation and use of improved technologies, such as improved land management, use of improved seed, provision of continuous training and other appropriate supports.

Extension contact is a very important variable that positively influenced the decision to practice crop rotation with lupin. Since extension services are the main instrument used in the promotion of best farming practices, timely and adequate extension services should be provided. Therefore, it is important to design appropriate capacity building program for development agents (DAs), like on job training. Moreover, recruit additional development agents is necessary to reduce burden of DAs.

\section{Acknowledgments}

The authors would like to acknowledge ELFF (Ethiopian Lupin for Food and Feed) project for the financial support to do the survey work. Our thanks also go to the local extension workers and farmers in the study districts.

\section{REFERENCES}

BACHEWE, F. N., BERHANE, G., MINTEN, B. and TAFFESSE, A. S. (2015). Agricultural growth in Ethiopia (2004-2014): Evidence and drivers. ESSP II Working Paper 81. Washington, D.C.: International Food Policy Research Institute (IFPRI). http://ebrary.ifpri.org/cdm/ref/collection/p15738coll2/id/ 129782.
BELSKI, R., MORI, T. A., PUDDEY, I. B., SIPSAS, S., WOODMAN, R. J., ACKLAND, T. R., BEILIN, L. J., DOVE, E. R., CARLYON, N. B., JAYASEENA, V., and HODGSON, J. M. (2011). Effects of lupin enriched foods on body composition and cardiovascular disease risk factors: a 12-month randomized controlled weight loss trial. Int. J. Obes., 35(6), 810-819. DOI: $10.1038 /$ ijo. 2010.213

CSA (Central Statistical Agency) (2017). Agricultural Sample Survey, Vol II. Report on Livestock and Livestock Characteristics by Private Peasant Holdings. Statistical Bulletin 585. CSA, Addis Ababa, Ethiopia.

CSA (Central Statistical Agency). (2014). Agricultural sample survey 2013/14 (2006 E.C.). Volume 4. Report on land Utilization by Private Peasant Holdings. Statistical Bulletin, number 446. Central Statistical Agency, Addis Ababa, Ethiopia.

DAVID, J.S., DAWIT, K. and DAWIT, A. (2011). Seed, fertilizer, and agricultural extension in Ethiopia, Ethiopia Strategy Support Program II. International Food Policy Research Institute (IFPRI). http://www.ifpri.org/publication/seed-fertilizer-andagricultural-extension-ethiopia.

DADO (District Agricultural Development Office). (2017). Respective Districts' basic information. Unpublished.

EDHS (Ethiopia Demographic and Health Survey). (2016). Ethiopia Demographic and Health Survey 2015, Addis Ababa, Ethiopia.

EEA (Ethiopian Economic Association). (2012). Annual report on Ethiopian economy. Addis Ababa, Ethiopia.

European Union Directorate General for the Environment (EU DGE), F.O.T.E.E., IFOAM EU Group and PAN. (2012) Crop rotation: Benefiting farmers. The Environment and the Economy.

FAO (Food and Agriculture Organization of the United Nations). (2004). Tropical Livestock Units (TLU). Virtual Livestock Centre, Livestock and Environment Toolbox. Rome. Available at http://lead.virtualcentre.org/en/edc/toolbox/Mixed1/TLU. htm, accessed on April 20, 2016

GETACHEW, S. and RANJAN, R. (2012). Growing Vulnerability: Population Pressure, Food Insecurity and Environmental Degradation, Central Rift Valley, Ethiopia. J. Biodiv. Env. Sci., 2(3), 33-41.

GUJARATI, D.N. (1995). Basic econometrics. 3rd Edn., New York: Mc Graw Hill, Inc.

HOSMER, D.W. and LEMESHOW. (1989). Applied logistic regression. A Wiley, Inter-Science Publication. New York.

IFPRI (International Food Policy Research Institute). (2010). Fertilizer and soil fertility potential in Ethiopia: Constraints and opportunities for enhancing the system. Working Paper.

ISRAEL, G. D. (1992). Sampling the evidence of extension program impact. Program evaluation and organizational development, IFAS, University of Florida. PEOD-5. http://edis.ifas.ufl.edu/pd005

KIRKEGAARD, J., CHRISTEN, O., KRUPINSKY, J. and LAYZELL, D. (2008). Break crop benefits in temperate wheat production. Field Crops Research 
107:185-195.

https://doi.org/10.1016/j.fcr.2008.02.010

KOTHARI, C. R. (2004). Research Methodology: Methods and Techniques, 2nd Edition. New Age International, New Delhi, India.

LAMBERS, H., CLEMENTS, J.C. and NELSON, M.N. (2013). How a phosphorus-acquisition strategy based on carboxylate exudation powers the success and agronomic potential of lupin (Lupinus, Fabaceae). American Journal of Botany 100:263-288. DOI: 10.3732/ajb.1200474

LMP (Livestock Master Plan). (2014). Roadmaps for Growth and Transformation. Developed by the LMP team for the Ministry of Agriculture, Livestock Resources Development Sector.

LEE, Y. P., MORI, T. A., PUDDEY, I. B., SIPSAS, S., ACKLAND, T. R., BEILIN, L. J. and HODGSON, J. M. (2009). Effects of lupin kernel flour-enriched bread on blood pressure: a controlled intervention study. American Journal of Clin. Nutr. 89(3), 766-772. DOI: 10.3945/ajen.2008.26708

MOLLA, H., AGRAW, A., LIJALEM, A., SHIGDAF, M., YESHIWAS, T., BERHANU, D. and LISANEWORK, M. (2017). Pre-Extension Demonstration of Sweet Lupin Grain Feeding for Washera Sheep Fattening at Debre Mewi Watershed of Western Amhara Ethiopia. Amhara Agricultural Research Institute, Andassa Livestock Research Center, Bahir Dar Ethiopia. International Journal of Agricultural Extension. 05 (03), 71-73. http://www.escijournals.net/IJAE

PEOPLES, M.B., BROCKWELL, J., HERRIDGE, D.F., ROCHESTER, I.J., ALVES, B.J.R., URQUIAGA, S., BODDEY, R.M., DAKORA, F.D., BHATTARAI, S., MASKEY, S.L., SAMPET, C., RERKASEM, B., KHAN, D.F., HAUGGAARD, N.H. and JENSEN E.S. (2009a). The contributions of nitrogen-fixing crop legumes to the productivity of agricultural systems. Symbiosis 48, 1-17. DOI: 1 10.1007/BF03179980
SEYMOUR, M., KIRKEGAARD, J.A., PEOPLES, M.B., WHITE, P.F., and FRENCH, R.J. (2012). Break crop benefits to wheat in Western Australia insights from over three decades of research. Crop and Pasture Science 63:116. DOI: https://doi.org/10.1071/CP11320

YEHEYIS, L., KIJORA, C., MELAKU, S., GIRMA, A. and PETERS, K.J. (2010). White lupin (Lupinus albus L.), the neglected multipurpose crop: Its production and utilization in the mixed crop-livestock farming system of Ethiopia, Livestock Research for Rural Development, 22 (4), 2010. http://www.1rrd.org/lrrd22/4/yehe22074.htm YEHEYIS, L., KIJORA, C., WINK, M., and PETERS, K. (2011). Effect of a traditional processing method on chemical composition of local white lupin (Lupinus albus L.) seed in northwestern Ethiopia. Zeitschrift für Naturforschung C, Volume 66, Issue 7-8, Pages 403-408, ISSN (Online) 1865-7125, ISSN (Print) 0939-5075, DOI: https://doi.org/10.1515/znc-2011-7-812

ZEWDIE, W. 2015. Assessment of Livestock Production System and Feed Resources Availability at Melka Watershed of Nile Basin, Jeldu District, Western Ethiopia. Global Journal of Science Frontier Research: D Agriculture and Veterinary. Volume 15, Issue 9. https://journalofscience.org/index.php/GJSFR/article/do wnload/1686/1547/ 